\title{
The Papal Aggression of 1850: A Study in Victorian Anti-Catholicism
}

\author{
WALTER RALLS
}

For those wishing to generalize about the Victorians the Great Exhibition of 1851 usually proves irresistable. But it does seem an obvious omission that so little is said about the disorders which kept the country upended during the preceding six months, that is, during the episode of the restoration of the Roman Catholic hierarchy, the "Papal Aggression." Christopher Dawson has urged that the one needs the other to symbolize properly the Victorian frame of mind. Here I wish to outline the underlying causes of this last great outburst of No-Popery feeling in an effort to trace the paradox of the aroused, angry, bigoted Guy Fawkes Day-men of November appearing the next summer as the staid, curious and progressive-minded citizens sunning themselves in the glory of all that glittering machinery so carefully displayed beneath the vaulted glass dome of their Crystal Palace. ${ }^{1}$

To begin, Lord John Russell, then prime minister, seems badly miscast as the leader of No-Popery sentiment, for he had attacked the Tories for decades for mixing anti-Catholicism with politics. Six years earlier during the bitter debate over the Maynooth grant (begun during the French Revolution for the support of an Irish Roman Catholic seminary) he had argued that it was no wonder Catholics refused to consider office under the Tories: "I ask, what men of the smallest spirit would join a party which treats with such contumely, such insult and such flagrant injustice, the body of Roman Catholics, professing the ancient

1. Unfortunately, Christopher Dawson did not himself undertake such a study, but see his comments, "The Victorian Background," The Tablet, 23 September 1950, p. 245. For a satisfactory narrative account of the Papal Aggression, see cl. 4, "Lord John Russell," in Owen Chadwick, The Victorian Church (London, 1966), 1. The centennial volume, The English Catholics, 1850-1950, ed. G. A. Beck (London, 1950), has several pertinent articles, including Gordon Albion, "The Restoration of the Hierarchy," pp. 86-116. More monographic is E. R. Norman, Anti-Catholicism in Victorian England (London, 1968), pp. 52-79, and Thomas P. Joyce, "The Restoration of the Catholie Hierarchy in England and Wales, 1850: A Study of Certain Fublic Reactions"' (Ph. D. diss. Gregorian University, Rome, 1966). The recent literature on Victorian Catholicism is summarized by Josef L. Altholz, "Writings on Victorian Catholicism, 1945-1970," The British Studies Monitor 2, no. 3 (Spring 1972):23-30. Altholz argues that while much is being published it remains excessirely pietistic, favors biograpby (with studies of Newman, Acton and Manning still dominant) and, though much is scholarly, remains largely uncritical. For a broader coverage of recent Victorian religious history which includes some instructive comments on English Catholicisn, see Richard A. Soloway, "Church and Society: Recent Trends in Nineteenth Century Religious History," The Journal of British Studies 11 (1972):142-159. A comprehensive study of Victorian anti-Catholicism has yet to appear; Norman's brilliant essay only points the way, as does G. F. A. Best, "Popular Protestantism in Victorian England," in Ideas and Institutions of Victorian Eritain: Essays in Honour of George Kitson Clark, ed. Robert Robson (London, 1967), pp. 115-142. Prior to these was Gilbert A. Cahill, Irish Catholicism and English Toryism, 1832-1848: A Study in Ideology (Ann Arbor, Mich.; University Microfilms, 1954). For the roles played by various leading individuals, see Brian Fothergill, Nicholas Wisenan (London, 1963); David Newsome, The Parting of Friends, The Wilberforces and Henry Manning (London, 1966): Meriol Trevor's massive Newman: The Pillar of the Cloud and Newman: Light in Winter (London, 1962). A more critical view of Newman during the crisis of the Papal Aggression is Ronald Chapman, Father Faber (London, 1961). Newsome's study is the model for what is required.

Mr. Ralls is professor of history in Hobart and William Smith Colleges, Geneva, New York. 
religion of Europe, and forming more than six millions of people of Ireland?" His career had been virtually punctuated by such statements as "on the principle of general religious liberty. . . . I will give my support to any question that may come before the House."2

But in his letter to the bishop of Durham, written on the eve of Guy Fawkes Day 1850, the stand of a lifetime was swept aside. The opening sentence was, "My Dear Lord: I agree with you in considering the 'late aggression of the Pope upon our Protestantism' as 'insolent and insidious,' and I therefore feel as indignant as you do upon the subject." The letter, made public to the nation, concluded, "But I rely with confidence on the people of England and I will not bate a jot of heart or hope as the glorious principles and the immortal martyrs of the Reformation shall be held in reverence by the great mass of a nation which looks with contempt on the mummeries of superstition and with scorn at the laborious endeavours which are now making to confine the intellect and enslave the soul."3

The occasion for this outburst was the reinstitution of a national hierarchy for Roman Catholics: England and Wales, after September 29, 1850, were to be divided among twelve dioceses headed by regular bishops under canon law with the highest authority being vested in the newly announced office of "CardinalArchbishop of Westminster." Since the seventeenth century, English Catholics had been under a type of church organization reserved for mission lands as in China, India and Oceania. It was a form of government headed by vicars apostolic instead of bishops, and directed immediately by the Congregation of Propaganda at Rome.

This change for English Roman Catholics would seem to have been unexceptional, especially since in the previous decade similar arrangements had been made for Quebec and Australia. In Ireland of course such a hierarchy had never ceased to function. However, when the papal brief announcing it was made known in England in late October 1850, there began a national outcry that swept along nearly every shade of the press and the pulpit with the established church and much of dissent joined in a most uncharacteristic show of unity. ${ }^{4}$ The Times soon found the appropriate label and from then on it was everywhere known as the Papal Aggression. Thousands of petitions to the Crown urged some form of retaliatory action, as did some seven thousand meetings, chaired by indignant local leaders. From November and the publication of Russell's Durham Letter no event could rival its continued fascination for the public. The Parliament of 1851 wasted itself on efforts to create new No-Popery legislation, efforts which finally met some returning sense of proportions, for the Ecclesiastical Titles Bill when passed that August was only a sop to bigotry and remained quietly on the books until Gladstone, opposed to the furor from the first, secured its removal some twenty years later.

Here I wish to explore why the Protestant majority felt so threatened and made so much of the issue; why in fact England at mid-century proved a most in2. Debates (Commons), 72 (13 February 1844). col, 699; 17 (23 Mareh 1827) col. 14.

3. The Times, 7 November 1840. This most famous of all Victorian assaults on English Catholicism is reprinted in English Historical Documents, ed. G. M. Young and W. D. Handcock (New York, 1956), 12 pt. 1:367-369. The bishop of Durham, Dr. Maltby, had publicly complained to Russell about the "insolent and insidious" nature of the restoration of the hierarelyy. Disraeli, assuming an amused attitude toward all parties, said, "I am bound to state that. . I never knew a proceeding more free from the appearance of sublety and covin." Debates (Commons), 114 (4 February 1851), col. 132.

4. But see below for the ambivalence felt by many dissenters in thus supporting the elaims of the national church. 
appropriate place for the Vatican to assert in any formal way a revival of Catholic authority. The question includes what led Englishmen at the height of their power to find in the ancient cry of "No-Popery" so apt an outlet for their strongest fears and self-doubts.

There are four aspects to the nature of the Catholic threat. First there is the fact that the number of Catholic believers had increased some twenty-fold, from thirty thousand at the turn of the century to perhaps three-quarters of a million by 1850.5 Nearly all of this was due to the Irish immigration and had come about within the laste decade. The heart-breaking experience of the Irish arriving by the hundreds of thousands, penniless, half-starved, half-clad, living in squalid rooms unfortunately only worsened the prejudices already surrounding Roman Catholicism in England. During the severe social and economic discontent of the 1840s, the English poor found themselves in direct economic competition with this new labor force. Carlyle drew the stereotype when he wrote in his wild fashion: "Crowds of miserable Irish darken all our towns... He is the sorest evil this country has to strive with. In his rags and laughing savagery ... he lodges in any pig hutch or dog hutch, roosts in outhouses. . . The Saxon man may be ignorant, but he has not sunk from decent manhood to squalid apehood."B This merging of the Irish poor with the old stigma attaching to the ancient faith raised popular anti-Catholic feelings to a new intensity.

The second point is that during this period there is renewed insistence on the old charge that Catholicism was incompatible with English political institutions. Since the mid-thirties the Tories had made an attack on Catholicism, its priesthood and doctrines, a major part of their objection to the Whig-O'Connell connection. The Times, the Quarterly Review, the Protestant Association, Exeter Hall and a score of other sources reinforced the charge that Catholics were priestdominated, owed their ultimate allegiance to a foreign power and were unable to fulfill their obligations as loyal citizens. Such charges and the replies they evoked from the Whigs, the Radicals and eventually the Peelites, made up a surprisingly large part of the political dialogue from 1835 to $1850 .^{7}$

On the other hand liberal opinion though somewhat more careful of the niceties of civil and religious liberty was itself deeply opposed to Catholicism. A correct definition of liberalism according to Matthew Arnold in Culture and Anarchy must include as a cardinal tenet the "Protestantism of the Protestant religion." 8 According to this view the progressive nations of the world, economically and politically, were those with a predominately Protestant faith.

5. E.E.Y. Hales, The Catholic Church in the Modern World (New York, 1958), p. 108. Census of Great Britain, 185.1; Religious Worship: England and Wales (London 1853), pp. cii, cxlvi, exlviii, xlvi. G. Kitson Clark, The Making of Victorian England (Cambridge, Mass., 1962), pp. 165ff. A cautionary note on the use of the Religious Census of 1851 is in W.S.F. Pickering, "The 1851 Religious Census-A Useless Experiment," British Journal of Sociology 18 (1967): 382-407. This should be compared with David Thompson's earlier article, "The 1851 Religious Census: Problems and Possibilities," Victorian Studies 2 (1957):87-97.

6. Thomas Carlyle, "Chartism," Critical and Miscellaneous Essays (London, 1907), 4:138. For a study of the Irish immigration in depth in one city (Cardiff) see John Hickey, Urban Catholics: Urban Catholicism in England and Wales from $18 \% 9$ to the Present Day (London, 1967). A broader scope is attempted in Lewis $\mathrm{P}$. Curtis, Anglo-Saxons and Celts: $\boldsymbol{A}$ Study of Anti-Irish Prejudices in Fictorian England (Bridgeport, Conn., 1968). For a review of other recent studies in local social-religious history, see Soloway, pp. $151 \mathrm{ff}$.

7. Cahill has been most enterprising on this theme in his Irish Catholicism and English Toryism, 1852-1848: A Study in Ideology.

8. Matthew Arnold, Culture and Anarchy (Ann Arbor, Mich., 1965), p. 106. 
The Dublin Revieze which was founded in 1836 by Nicholas Wiseman and other leading Catholics largely to refute the more grotesque misunderstandings regarding their faith, and which hoped to meet the Edinburgh and Quarterly reviews on some level of parity in its critical and historical writing, returned repeatedly to this charge (despite its name, it was always published in London). In an article entitled "Arbitrary Power, Popery, Protestantism", it was conceded that no article of the national creed had been inculcated more successfully than that both "popery and arbitrary power" were "inseparable." This had been so long taught without contradiction, the article said, "that we fear the majority of Protestants, in both kingdoms now regard it as a religious-political axiom." And then the author sets himself the imposing task of proving that "it has been from the earliest period the doctrine of Catholic writers, that the people were the only legitimate source of all civil authority." In a subsequent piece, "Prejudices of our Popular Literature", it was observed that England was the "slave of prejudice" despite her boasted liberty. It was the prejudice of both patriotism and religion, for in England these were one. "It is the growth of centuries, deepening in its dye as each year rolled on, becoming every day more inveterate in its hold upon the public mind."10

The third factor contributing to anti-Catholicism in 1850 was that during the previous decade Catholicism in England had become, rather suddenly, revitalized and impressive in its enthusiasm for challenging the position of the Protestant majority, and especially of the established church. To the old hereditary Catholics and the immigrant Irish there was added in the thirties and forties a remarkable group of young, well-born converts who brought intelligence, money, position and above all great enthusiasm for the task of winning England again for the faith.

A. W. Pugin, the famous proponent of neo-Gothic architecture and a recent convert, built the first monastery since the Reformation. It was followed by a variety of schools, chapels, churches and in 1848 the dedication of the first cathedral since the sixteenth century, St. George's in Southwark. A score of prelates from the continent attended the brilliant ceremony and the publicity was nationwide. Ambrose Phillipps and other rich converts helped bring various Italian monastic orders to engage in open-air missionary work. Here again there was much notice taken of the public processions in sandals and flowing robes, with

9. Anon., Dublin Review \& (February 1840):6-10.

10. Ibid., p. 57. Protestant antagonism towards Catholicism extended as everyone knows far beyond the classical doctrinal differences. Best has been illuminating and amusing about the intense alarm Victorians experienced when confronted with the world of convents, monasteries and the confessional. Still, as he himself urges, these are important matters and as yet await extended treatment. No one, for instance, has explored the social meaning of that great body of early Victorian literature (popular and scholarly) on the prophetic interpretation of Daniel and the Revelation with their master symbols supposedly pointing to "the mystery of iniquity" and the "anti-Christ." Eren more neglected are the controversies over Saint Alphonsus Liguori (1696-1787) whose works were translated into English during this time. A major influence throughout nineteenthcentury Catholic theology, Liguori is credited with shaping the definition of the dogmas of the Immaculate Conception and the infallibility of the pope. His Theologia moralis (9th ed., 1785) was fiercely attacked by Protestants for its liandling of such sins as lying and theft. Even more disturbing to an age traumatized by any hint of sexual symbolism was his graphic devotional study (Le glorie di Maria, 1750) on the relation to the Virgin to Christ and the Father. The Dublin Review repeatedly comes to the defense of the great Redemptorist theologian. There was also considerable public interest (see almost any issue of the Annual Register) in the numerous law suits charging that property had been granted to the Catholic bishops (indirectly for the law forbade direct gifts) because of undue influence in the confessional. This, clearly, hardly begins the subject of Victorian anti-Catholicism. 
statutes of the Virgin in prominent display-sights not seen in England for hundreds of years, and accompanied now by frequent ugly mobs. ${ }^{11}$ Among the monastic orders heretofore unknown to England were the Trappists, Redemptorists, Passionists and the Fathers of Charity, now all in their distinctive garb. ${ }^{12}$

The papacy, long out of touch with affairs in England, was led to believe, especially by the ebullient Wiseman, that a new day had indeed dawned, and after 1845 and the conversion of Newman and other Oxford Anglicans, there was a widely held opinion in Rome that all of England might return to the ancient faith. The journal of ultramontane French Catholicism, L'Univers, gave European prominence to these events, though the facts were somewhat less than these reports implied. ${ }^{13}$

At the center of this new activity was Nicholas Wiseman. Born at the turn of the century, he had a phenomenal career at Rome after attending a small parochial school in England. While still in his twenties he had become the head of the English College in Rome, agent for the vicars apostolic (among whom he got a bad reputation for politics), and still had time to win an international reputation as a scholar for his textual studies on ancient manuscripts in the Vatican library. At the same time his exuberant nature had carried him into the social world of Rome and he was early accounted a public figure and a great preacher. Everyone knew him. When the new English converts came to Rome in the thirties he proved a sympathetic advisor and friend, and he began to share their dream of the reconquest of England for the faith. The Dublin Review was to be the special instrument for this end, and it was important in convincing the later converts of the forties that Newman's doctrine of the via media was incompatible with a true history of the church. Newman, as is well known, credits one of Wiseman's articles as having started him on the road to Rome. ${ }^{14}$ Wiseman had come to England permanently in 1840 and had thrown himself into the work of public lectures, organizing the new changes in ritual and worship along more Italian (and thus controversial) lines, raising money for Pugin's buildings, and trying to solve the problem of how best to assimilate the Irish into the English Catholic world. His style of writing and address ranged from carefully reasoned polemics to what even his contemporaries deemed lugubrious sentimentality. As his energies became ever more diversely directed the unfortunate tendencies in his style predominated. It is significant that after becoming cardinal-archbishop in 1850, his one major effort was the novel Fabiola, an immensely popular romance of the early Christians. As the choice in 1850 to head the new hierarchy, Wiseman's fondness for ornate display and his tendency towards orotund rhetoric made him an extremely visible target for Protestant antagonism. Brilliant, ver-

11. Denis R. Gwynn, The Second Spring: 1818-1852 (London, 1942); and by the same author, Father Dominic Barberi (London, 1947); Ambrose Phillipps (later de Lisle), "Supplement: Letters of Father Dominic of Mother of God," The Life of the Blessed Paul of the Cross (London, 1853), 3: Urban Young. Dominic Barberi in England (London, 1935); E. S. Purcell, Life and Letters of Ambrose Phillipps de Lisle (London, 1900); Bernard Ward, The Sequel to Catholic Emancipation (London, 1915); Claude R. Leetham, Luigi Gentili: A Sower for the Second Spring (Iondon, 1965).

12. Protestants were not the only ones to take exception to this flowering of Italian Catholicism. The hereditary English Catholies (the "Old Catholies") deeply resented these (to them) un-Fnglish and unnecessary innovations. See especially B. Ward and Leetham.

13. James MacCaffrey, History of the Catholic Church in the Nineteenth Century (2nd ed., Dublin, 1910), 2:49ff., is an extended review of Vatican-English Catholic relations in the generations before 1850 .

14. Apologia Pro Vita Sua (New York, 1956), p. 218. 
satile, ambitious and dedicated as he was, still he could appear a pompous fool. ${ }^{15}$

My fourth observation has to do with the sharp contrast between a seemingly monolithic Catholic faith, revitalized and expanded, and the disarray in which Protestantism found itself at mid-century. This is a subject obviously unto itself, and here I wish to make only the broadest of connective statements. The established church was riven between the evangelical, the Arnoldian broad and the ritualistic high church factions. Central to the confusion was the Oxford Movement. Probe at virtually any point, and the bitterness and hostility will seem a hundred and twenty years later to be palpable and alive. From Dr. Arnold's first bitter attack in the Edinburgh Review, entitled "The Oxford Malignants, and Dr. Hampden", wherein he called the Tractarians "the peculiar disgrace of the Church of England", through the publishing of Hurrell Froude's mildly scandalous Remains, and then the almost ludicrous effort to establish with the German Lutheran Church a joint bishopric of Jerusalem-bringing upon the British government in 1841 a protest from Turkey not dissimilar to that expressed by the English parliament ten years later against the "Papal Aggression"16_through the issuing of Tract 90 with the resultant outcry from all sides, including those most kindly disposed toward the Tractarian movement (here the master of Trinity, Christopher Wordsworth, is typical when he cried, "Oh, what a fall! Its persual has lowered my opinion of the writer more than I could have thought possible"), there is an atmosphere of unrelieved tension which had not abated by $1850 .{ }^{17}$

The Puseyite ritualists, if no one else, were enough to keep raw nerves from healing. Every weapon was used against them: sarcasm, supercilious and frosty disdain, ecclesiastical censure and finally court action. But they held their own, an acerbating minority estimated as some five percent of the clergy who were a constant reminder of the tendency toward Rome and the prior claims of the ancient church. It can be argued that there was more actual antagonism directed toward them during the uproar over the Papal Aggression than toward the Roman Catholics. Lord John Russell's loss of equilibrium can most directly be charged against his high irritation with the Puseyites, for in the Durham Letter he said, "What, then, is the danger to be apprehended from a foreign prince of no great power, compared to the danger within the gates from the unworthy sons of the Church of England?"18

Still, the ritualists and the conversions to Rome were but part of the problems facing the Protestant majority by 1850. From the agnostic left came the new geology and earth sciences and by the forties a wide reading in German theology and the higher criticism to contest not only the Mosaic cosmology but classical Christian doctrine itself. Gladstone reported that for him reading Schleiermacher opened the "sluices of the theological deep whether to deluge or to ir-

15. For depth of presentation Wilfred Ward, The Life and Times of Cardinal Wiseman (London, 1897), 2 vols., is richer than the recent work by Fothergill.

16. Thus Faud Effendi put to Aberdeen, at the Foreign Office, a series of questions which closely parallel those put to Rome by the British ten years later: Did not the British government concede that the Jerusalem bishoprie was unduly ambitious, including as elaimed, all of Syria, Palestine, Chaldea, Egypt and Abyssinia" "And since he exercised this "jurisdiction' under the metropolitan control of a foreign pontiff", one question read, "was not this violation of the sovereignty of the sultan in his dominions, a derogation, so to say, of the sultan's royal supremacy," $R$. W. Greaves, "The Jerusalem Bishopric, 1841," The English Historical Review 64 (July 1949):350.

17. Thomas Arnold. "The Oxford Malignants and Dr. Hampden," The Edinburgh Review 63 (April 1836) :235. For the Worlsworth quotation, A. B. Webster, Joshua Watson: the Story of a Layman, 177 1-1885 (London, 1954), p. 108.

18. Young and Handeock, 12, 1:368. 
rigate, I do not know." This is not the place to explore how wrong G. M. Young was in writing that "English divinity was not equipped to meet-for its comfort, it was hardly capable of understanding-the new critical methods of the Germans", but the evidence runs the other way. ${ }^{19}$ And it is instructive that when Bishop Blomfield answered a petition signed by some seven thousand clergy regarding the Papal Aggression he chose to say, "I cannot but think that we have more to apprehend from the theology of Germany than from that of Rome; from that which deifies human reason, than that which seeks to blind or stifle it."20

Further anxiety was occasioned by the widespread concern over the proper definition of church-state relations. The profound impact of Coleridge and his view of the common identity of church and state had met a sharp setback in the post-1832 (the Great Reform Bill) world of ecclesiastical commissions and the newly insistent voice of dissent that the Anglican church should be disestablished. Church and dissent had since the seventeenth century never been further apart; one of the great authorities on the period (Kitson Clark) refers to "the hatred entertained for the Church of England by many of those who dissented from it."21 Examined individually, the various denominations and sects were either experiencing a sharp contest for authority within their ranks as in Methodism, or an unsettling decline in growth relative to the population. All dissent of course still suffered grave social and educational disadvantages. It would not be until later in the next decade that a new wave of enthusiasm and growth would begin for the nonconforming bodies. At the time of Papal Aggression dissent shared with the established church a crisis of confidence which made the Catholics appear all the more formidable. ${ }^{22}$

Significantly, dissent, though early swept along by the mighty surge of NoPopery, soon had second thoughts. For them to join the national church in a protest against the Catholic challenge to its jurisdiction in England would only serve to strengthen the former. Caught between two, not one, ancient enemies, the leading dissenting parliamentary spokesman, John Bright, vigorously opposed Russell's Ecclesiastical Titles Bill, which the government introduced early in the life of the parliament of 1851 . He had of course other grounds for opposition: Russell's speech on the seventh of February he found "very good if delivered some 300 years ago" and along with many thinking members of the house (Gladstone, Graham, most of the Peelities and of course the other Radicals, Roebuck and so on) condemned the illiberality and inanity of forbidding under penal threats any ecclesiastical organization other than the established church from assuming territorial titles. But Bright also spoke for dissenters when he argued: "The measure is nothing better than a sham. I believe the only effect of it can be an attempt

19. John Morley, The Life of William Ewart Gladstone (New York, 1903), 1:166, G. M. Young, Dictorian England (New York, 1954), p. 114. See Duncan Forbes, The Liberal Anglican Idea of History (Cambridge. Mass., 1952). On the early recognition of German textual eriticism, see Merton A. Christensen, "Taylor of Norwich and the Higher Criticism," The Journal of the History of Ideas 20 (April 1959):183. See also A.O.J. Cockshut, The Unbelievers: English Agnostic Thought, 1850-1890 (London, 1964) ; Anthony Symondson, The Victorian Crisis of Faith (London, 1970).

20. The Morning Chronicle, 4 November 1850.

21. Clark, p. 158.

22. Ibid., especially $\mathrm{ch}$. 6, "The Religion of the People." See also Elie Halévy, $A$ History of the English People in the Nineteenth Century, Vol. 4: Victorian Years, 1841-1895 (London, 1961): 337-414. Maldwyn Edwards, After Wesley (London, 1943). E. R. Taylor, Methodism and Politics, 1791-1851 (Cambridge, 1935). John T. Wilkinson, 166\% and After: Three Centuries of English Nonconformity (London, 1962); John Kent, The Age of Disunity (London, 1966) is excellent on Methodism. 
to bolster up the ascendency so long maintained by the Church Establishment."23

No-Popery in 1850 then may be explained in part by the four factors of 1) the Irish immigration; 2) the old charge of Catholic alienation from true English values intensified by the politics of the thirties and forties; 3 ) the publicity given Wiseman and the converts; and 4) the unsettled condition of Protestantism. The evidence would appear to support Halévy's judgment: "By birth or choice, Catholics were aliens at home. The history of the growth of English Roman Catholics is no part of the English history." 24

The simplicity of this statement is, however, misleading. As an observation that in the nineteenth century (the period Halévy focused on) Catholicism in England led a life of its own and Catholics were only partially assimilated into the dominant culture of the Protestant majority, the statement stands. But surely one is not left to infer that Catholicism may be eliminated from a study of the Victorian world. For one thing the Victorians were saturated with a sense of history, far more than we who have the alternative rhetoric of the social sciences to rely upon. History for them was virtually the only instrument of investigation and analysis and in the hands of Macaulay, Lecky, Froude and others, it produced the Whig interpretation that England's present pre-eminence was closely associated with the values and ideas of Protestantism. And in their pages invidious anti-Catholic comparisons abound.

Yet for all their belief in "progress" the Victorians clearly were uneasy. Their novelists and prophets were only too aware that the authority of Protestantism was under severe attack. What would replace it, or possibly renew it, had not yet appeared. Then for the ancient authority at Rome to be experiencing a "second spring" was doubly disturbing. And when the Vatican sent the first Cardinal the English had seen since the Reformation to rule a church now announced as coterminous with the established church, all the old associations of No-Popery were sharply intensified.

Several events in 1850 made that year most unpromising for such a venture. Vatican policy and Catholic affairs generally in Europe were harshly regarded in England. While at home the Gorham Judgment proved the most unsettling event since Newman's defection to Rome. In Ireland there was the seemingly interference in secular matters by the Catholic hierarchy, a considerable cause of alarm to the government, for since the death of O'Connell (1847) and the sudden demise of Smith O'Brien and the Militan Young Irelanders (1848) there was a vacuum of leadership, which if filled by the Catholic clergy would mean trying days ahead.

As regards the pope, Pius IX had begun his reign in 1846 with an almost popular press in England. The Times playfully referred to him as "Pio Nono" and applauded his first mildly liberal measures in the papal estates. But the revolutions of 1848 killed this mood when he had had to make his hasty and ignominous flight to Naples, a place widely regarded in England as having the most corrupt, reactionary government in Europe. Gladstone in 1850 had just returned from there, "boiling with indignation" over the plight of liberal Neapolitan politicans wasting in dark solitary confinement. ${ }^{25}$ As always Gladstonian indignation was good press. And bad for the pope for having sought asylum there. Nor did his re-

23. George Macaulay Trevelyan, The Life of John Bright (New York, 1913), p. 193.

24. Halévy, p. 376.

\$5. Ibid., p. 317 . 
cent return to Rome in the spring of 1850 under the protection of French troops help, for it revealed how unpopular his leadership had become to his own people. His angry struggle that summer with the liberal Sardinian government of d'Azeglio completed English disillusionment. It was this pope, then, who issued the papal rescript, derisively called the "Papal Bull", ${ }^{26}$ in October establishing Wiseman and his hierarchy in England.

At home Palmerston was in his most John Bullish mood and his refusal either to receive General Haynau, the leader of Austrian conservative forces in 1848, or to apologize to him or his government after the workers at Barclay's Brewery gave him a mild but nasty roughing, was generally regarded by Englishmen with fond approval. As for his great four-hour "Don Pacifico" speech in the House of Commons earlier that year, no expression of the pride in being English was to be so remembered throughout the century. The peroration it will be recalled ended with the stirring assertion that an Englishman anywhere in the world should be able to use his citizenship to invoke respect, just as in ancient times a Roman could rout opponents with the cry, "civis Romanus sum."27 1850 clearly was an awkward time for any foreign potentate to insult, no matter how unknowingly, English patriotism.

No-Popery feelings were even more directly aroused when the prolonged investigation of the theology of the Rev. G. C. Gorham came to a controversial end in 1850. An especially acerbating aspect was the fact that the final decision was handed down by a lay court, the Judicial Committee of the Privy Council. The Gorham case touched on all sides of the religious issue, but the most prominent feature was the ranging of the Puseyite wing solidly against Gorham. When the government validated his orthodoxy a storm broke over the head of the prime minister. Russell, who had systematically appointed only anti-Puseyite men to high ecclesiastical position now made no bones about his opposition and fear of the high church party. They were not only traitors to the church, he said, but also guilty of a "shocking profanation" by "turning a service of remembrance into an offensive spectacle."28

The Gorham Judgment was the occasion for a stream of new defections to Rome, Manning and Robert Wilberforce being only the more prominent members of this new party of converts who found their high church hopes crushed by this final intolerable event. A measure of the intense excitment the isste raised is the British Museum's collection of over two hundred books and pamphlets written in 1850 and the following year on the Gorham Judgment. ${ }^{29}$

26. In Vatican usage the document was referred to as a rescript or brief, but never a bull, which of course has a higher order of authority. These niceties were lost in the heat of the moment: "Papal Bull", certainly sounded more threatening, and the homonymic possibilities of such a word proved widely irresistable. Punch for weeks carried endless puns and cartoons about strayed, lost, charging and wounded bulls. The most famous cartoon, perhaps is a seene at a cattle show of an enormous bull with the face of Pius IX and the English public contemptuously walking away. The caption read, 'Great Cattle Show: The Roman Bull that Didn't Get the Prize." Equally abounding were the puns on "Wise-man", and "New-man." Punch threw itself with such vehemence into the uproar that their most distinguished artist, Dicky Dole, felt called upon to resign. Denis $R$. Gwynn, A Hundred Years of Catholic Emancipation: 1829-1929 (London, 1929), p. 107.

27. Halévy, p. 305.

28. Spencer Walpole, The Life of Lord John Russell (London, 1889), 2:116.

29. Though some ritualists joined in the general No-Popery cry (for reasong that may be imagined), many felt that they were the true point of attack and there began a general retreat from the time-honored policy of appealing to the secular power for support in sustaining the church. Gladstone who was frequently ranked witl them said he voted 
On the personal side, the ritual controversy had come to Russell in 1850 in a rather intense way. St. Paul's, Knightsbridge, where he and his wife worshipped, had become since its consecration in 1843 one of the most fashionable parishes in London. The curate-in-charge was W. J. E. Bennett, an able man, much dedicated to the social side of his ministry. As a consequence he asked his wealthy congregation to back the building of a church for the poor. This was completed and had just been consecrated on 11 June 1850 as St. Barnabas, Pimlico, or rather, according to the new style as S. Barnabas. Russell approved this work and gave it support.

At St. Barnabas, Bennett indulged his tendency toward high church ritual by installing a small college for choristers and four priests. His services included all the niceties of address and usage employed by the more daring Puseyites. After Russell wrote his Durham letter the press picked up charges recently made by Bennett's superior, the redoubtable Bishop Blomfield, against Romanizers in the church and focused on Bennett as a prime example. There was an ugly riot at St. Barnabas on the third Sunday in November. A mob broke in and the police were called. Bennett received threatening letters and a package filled with dung. Early in December he wrote a public Letter to Lord John Russell which pointed out that these were the true consequences of the prime minister's appeal to No-Popery, and, more telling, he related that for the past few years high church services which Russell now termed "mummeries of superstition" had been weekly practiced in St. Paul's, with no noticeable protest from his most distinguished parishoner. The Letter went through seven editions, and it could only have added to the difficulty Russell was having in keeping a sense of perspective on the issue of anti-Catholicism. ${ }^{30}$

Finally, perhaps the most alarming previous event of 1850 for Russell and his government regarding Catholic power took place in August at the Synod of Thurles. No such Irish national synod had been held since the early seventeenth century, and that now assembled was seen from Westminster as a pecular instance of revived papal authority. When the printate of all Ireland, the archbishop of Armagh, died late in 1849, Pius IX passed over the three names recommended by the Irish clergy and had instead appointed Dr. Cullen, a still youthful churchman then serving as head of the Irish College in Rome. Dr. Cullen was seen not only as a new broom-there had been some debilitating divisions in the Irish hierarchy-but as sharing that ultramontane spirit which so moved Wiseman and the English converts. The Russell government was made to feel his presence in an especially uncomfortable way: "One alarming spectacle of the present times", the new primate told the assembled prelates, "is the propagation of error through a godless system of education."31

This attack was aimed at the efforts of Peel and now supported and continued by Russell and the Whigs to make up for the inadequacies of Dublin University. This ancient institution, established in the closing years of Elizabeth $I$, had but one college, Trinity, and though more or less open by the nineteenth century

against the Ecclesiastical Titles Bill on its second reading "for the purpose of entering my protest against all attempts to meet the spiritual dangers of the Church by temporal legislation of a penal character." This is certainly an important by-product of the Papal Aggression. Debates (Commons), 115 (23 May 1851), col. 566.

30. Frederick Bennett, The Story of W.J.E. Bennett (London, 1909). For a suceinct account, see Chadwick, $1: 301 \mathrm{ff}$.

31. Peadar Mac Suibhne, Paul Cullen and His Contemporaries, with their letters from

1820-1920 (Kildare, 1962), $2: 56$. 
to attendance by others than members of the established church, in fact very few Presbyterians and fewer Catholics went there. Peel in 1845 had successfully introduced legislation to establish three new Queen's Colleges at Belfast, Galway and Cork. It called for an initial endowment of $£ 100,000$ for the buildings and $£ 6,000$ annually for upkeep. It was to be non-sectarian.

This principle of undenominational education ran counter to virtually all English schools at the time, from primary to the two older universities. Predictably a protest was made by nearly all camps on the right when Peel introduced his bill. That ardent champion of low church feeling, Sir Robert Inglis, called it "a gigantic scheme of godless education", and the phrase "godless colleges" stuck.:2 Now Dr. Cullen was using those very phrases. While at Rome he had been privy to the conflicting response the Irish hierarchy experienced when faced with this generous proposal. For Rome, however, there was only one correct position and the Sacred Congregation of Propaganda issued late in 1847 a papal rescript condemning the colleges. A year later in October a second rescript reiterated the prohibition. Lord Clarendon, then Irish Viceroy, rather desperately tried to reach an accommodation, for his government was going ahead with the buildings and the question was who was going to use them. Now at the Synod of Thurles six separate decrees were issued; the first prohibited anyone in orders from participating in the Queen's Colleges in any way, and in the sixth, the laity were warned "to repudiate and shun them on the ground they involved grave and intrinsic dangers to faith and morals." 33 It was not an absolute prohibition, but it was enough to render the scheme a failure (by 1858 the government reckoned over some $£ 380,000$ had been spent with less than 262 students taking degrees-the "godless colleges" were dissolved in 1882). ${ }^{\mathbf{3 4}}$

When early in the life of the parliament of 1851 Russell defended both his unwonted No-Popery and the need for penal legislation, he cited the recent Synod of Thurles as the kind of ecclesiastical interference which must be prevented. $\mathrm{He}$ referred to the "unusual manner" in which Rome had selected their own man as primate:

a clergyman who had long been resident at Rome . . . conversant with the habits and opinions of Rome. I must ask whether this House and the Government of this country can be entirely indifferent, when they see that an archbishop has been thus named ... and that the first proceeding he carries into effect is to hold forth to odium an Act of Parliament passed by this country for the purpose of educating the people of Ireland. . . . This I think, is an instance at all events, that we have not to deal with purely spiritual concerns; that that interference ... has been attempted as a beginning, no doubt, to be matured into other measures, and to be exerted on some future occasion with more potent results. ${ }^{\text {95 }}$

Everyone could understand this argument, whether agreeing or not. To the Catholic mind it was manifestly unfair, for the decisions taken at the Synod of Thurles were entirely appropriate to the pastoral functions of their bishops. But for most Protestants it mean that a major piece of social legislation, developed for the sole end of improving Ireland, had been repudiated and rendered ineffective by an authority unknown to the constitution and one accountable to no power in the Queen's realm. Some weeks earlier the Times addressed itself to the ques-

32. Debates (Commons), 80 (9 May 1845), col. 378.

33. Fergal MeGrath, Newman's Universily: Idea and Reality (London, 1951), p. 74.

34. Ibid., pp. 80,81 .

35. Debates (Commons), 114 (7 February 1851), col. 187-190. 
tion of the Synod of Thurles: "Is it not the very essence of this jurisdiction to insinuate itself into that of the State. . . Did not these spiritual and ghostly 'governors' of Ireland denounce and nullify the best-conceived measures of $\mathrm{Her}$ Majesty's Ministry for improving that miserable country?" And then making the jump to the Vatican's quarrel with the liberal government of d'Azeglio, the editorial continued, "Are not the same 'authorities' at this moment defying the Government and laws of Sardinia and waging open war there with the Crown?"36

These are some of the circumstances, then, surrounding Russell's and many others' loss of perspective and equilibrium when the papal rescript, Universalia Ecclesiae, announcing the new hierarchy, was published in full in the Times. Unfortunately for everyone it was Wiseman who had composed this solemn document, and to the question, "What was the Papal Aggression?", one must look as much to the matter of style as to the events themselves. For the infuriating element was not so much how the Roman Catholics organized their community in England, but rather the inflated and arrogant language used in announcing these changes. This "Papal Bull' dismissed the established church in such phrases as "the Anglican schism of the sixteenth century" and then declared "after having weighted the whole matter most scrupulously ... we have resolved and do hereby decree the reestablishment in the kingdom of England, and according to the common laws of the church, of a hierarchy of bishops deriving their titles from their own sees, which we constitute by the present letter in the various apostolic districts." It concluded with a direct challenge: "We decree that this apostolic letter shall ... always be valid and firm, and hold good to all intents and purposes, notwithstanding the rights of former sees in England. . . . We likewise decree that all which may be done to the contrary by anyone whoever he may be, knowing or ignorant, in the name of any authority whatever, shall be without force." 37

The Morning Chronicle said it appeared that all other ecclesiastical authority had been "stigmatized . . . as schismatic and intrusive." 38 And the extreme element in the Catholic press only made matters worse. The French ultramontane journal L'Univers declared that "since the promulgation of the Papal brief, the sees of Canterbury, of York, of London, and any other sees established before the reformation have ceased to exist. The persons who in the future may assume the titles of Archbishop of Canterbury, or Bishop of London will be nothing less than intruders, schismatic priests, without spiritual authority."39 The radical Catholic newspaper The Tablet, published then in Dublin but written primarily for the English, said that "Rome has more than spoken ... all baptized persons, without exception . . . are openly commanded to submit themselves in all ecclesiastical matters, under pain of damnation, and the Anglican sees, those ghosts of realities long passed, are utterly ignored." 40 These and other comments were extensively quoted in the English press.

But worse was to come: a week after the publication of the papal rescript, the Times on October 29 carried a copy of Wiseman's first pastoral letter to English Catholics. He wrote it while still traveling in Europe and before he knew of the

36. Times, 27 November 1850. A careful account of the "godless colleges" is in MeGrath, pp. 1-83. See also J. H. Whyte, The Independent Irish Party, 1850-9 (London, 1958).

37. The Times, 21 October 1850 .

38. 25 Oetober 1850.

39. Quoted in the Morning Chronicle, 23 October 1850.

40. The Tablet, 26 October 1850. 
outcry against Universalis Ecclesiae then breaking in England. Read today this first pastoral does seem an unbelievably grandiloquent document. $\mathrm{He}$ announced himself to be, "Nicholas, by the Divine mercy of the Holy Roman Church [known] by the title of St. Pudentiana Cardinal Priest, Archbishop of Westminster, and Administrator of the Diocese of Southwark." (Newman on reading it asked, "Who in the world is St. Pudentiana?"11) The pastoral went on to claim that, "at present and till such time as the Holy See shall think fit otherwise to provide, we govern, and shall continue to govern, the counties of Middlesex, Hertford, and Essex, etc." Wiseman continued, "England has been restored to its orbit in the ecclesiastical firmament, from which its light had long vanished, and begins now anew its course of regularly adjusted action round the centre of unity, the source of jurisdiction, of light and vigour." And then, in a burst of prose: "How much the Saints of our country, whether Roman or British, Saxon or Norman, look down from their seats of bliss, with beaming glance." Their former sadness at "the departure of England's religious glory" was over "as they see the lamp of the temple again enkindled and rebrightening, as they behold the silver links of that chain which has connected their country with the see of Peter in its vicarial government changed into burnished gold. . ..",42

The Times assumed a contemptuous tone: "that mongrel document, which reads like a cross between an Imperial rescript and a sermon addressed to the victims of an auto-da-fe." The Morning Chronicle declared that "nothing under heaven-no science and no art-can be pursued by Catholic and Protestant in common. Everywhere the old spiritual war cry is heard."43 Many Catholics were embarrassed and disheartened. Wiseman, who was still out of the country, had sent the pastoral to his assistant in London, Dr. Whitty, who was close to panic over the outcry already created by the publication of the papal brief. To Bishop Ullathorne he explained, "I could not withhold it. Still less could I dare suppress or tamper with any of its expressions at my own discretion. On the other hand, not a few were beginning to apprehend a repetition of the Gordon riots. . . After a short prayer for light, I decided on publishing the Pastoral just as it was." Ullathorne commented to Newman that he wished Whitty had asked "for a little human light as well." 44

But predictably the language used in reply and in the appeals to the government to take retaliatory action was just as intemperate. Mass meetings, over one

41. Wilfred Ward, Life of Newman (London, 1912), 1:168. Apparently no one has ever successfully answered Newman's question; the good saint was found questionable in the early $1960 \mathrm{~s}$ and removed from the roster.

42. The Times, 29 October 1850, printed Wiseman's Pastoral "Out of the Flaminian Gate," issued Oetober 7, 1850; it appears in Young and Handeock, 12, 1:364-367.

43. The Times, 29 October 1850. See also 4 November 1850; The Morning Chronicle, October 29; see also November 3, 4, 1850.

44. William Bermard Ullathorne, An Autobiography (London, 1891), 2:296. The old Catholics were especially dismayed. Their most prominent lay figures, the Duke of Norfolk and his son, gave up the faith, and the Duchess of Norfolk wrote a letter of embarrassed indignation to the Queen. See Arthur C. Benson, Letters to Queen Victoria, 1837-1861 (New York 1907), 2:325. The papal secretary, Mgr. Talbot, writing to Nassau William Senior said, "If we had had the slightest suspicion of the storm which we were about to excite, it would have been easy to avoid."' See E. E. Y. Hales, Pio Nono: A Study in European Politics and Religion in the Nineteenth Century (London, 1954), p. 142. As for the Old Catholic dream, and partly Wiseman's too, of finding acceptance without bigotry within the structure of English culture, that too was lost as the alienation so dramatically intensified by the Papal Aggression continued. Christopher Hollis has observed that 1850 "killed Roman Catholicism politically. It was all but impossible for a Catholic to get an English constitueney to elect him."' See his "Catholics in English Politics: 1850-1950," The Tablet, 23 September 1950, pp. 252-253. 
million signatures on petitions to the crown, declarations of civic and religious organizations, burnings of effigies and some ugly mob scenes ${ }^{45}$ and finally the excesses of the parliamentary debates over the Ecclesiastical Titles Bill in the session of 1851 all indicate that it was not simply Wiseman and Lord John Russell who had lost their balance.

We thus return to our opening remarks concerning the difficulty of understanding the Victorian balance: its enormous swing between things spiritual and things material. Within six months of the height of the Papal Aggression tumult the pendulum swung to another extreme, and the nation was absorbed in an entirely different national experience, that of the Crystal Palace and the Great Exhibition. Here, on display to the world, were sufficient grounds for their confident belief in progress, sufficient proof to support the many prophets who had held that social and political and above all material advancement was the true business of man. Some fifteen years before Macaulay had written, "To make men perfect was no part of Bacon's plan. His humble aim was to make imperfect men comfortable." 46

But the Victorians could not rest on this side of the equation either. Far more representative than Macaulay was the experience of Charles Kingsley. The Crystal Palace, he said, moved him to tears. To him "it was like going into a sacred place." And four days later in an exuberant sermon he announced, "If these forefathers of ours could rise from their graves this day they would be inclined to see in our hospitals, in our railroads, in the achievements of our physical science, confirmation of that old superstition of theirs, proofs of the kingdom of God, realization of the gifts which Christ received for men, vaster than any of which they had dreamed." 47 On the other hand, earlier that year he published his novel Yeast in which the hero Lancelot Smith is moved to write to a cousin recently converted to Rome:

When your party compare sneeringly Romish Sanctity, and English Civilization, I say, 'Take you the Sanctity, and give me the Civilization!... Give me the political economist, the sanity of the reformed, the engineer; and take your saints and virgins, relics and miracles. The spinning-jenny and the railroad, Cunard's liners and the electric telegraph, are to me, if not to you, the signs that we are, on some points at least, in harmony with the universe; that there is a mighty spirit working among us, who cannot be your anarchic and destroying Devil, and therefore may be the Ordering and Creating God. ${ }^{48}$

The Crystal Palace made many Victorians besides Kingsley uneasy ${ }^{49}$ for it

45. This is hardly the place to detail these ragged events; Guy Fawkes Day came at a most awkward moment, for the newspapers and various ecclesiastical meetings and charges had already begun to fill the air by then with the old No-Popery passions-Russell's Durham letter, however, though dated November 4, did not reach the press until after the Guy Fawkes riots had oceurred, though it was blamed then, and in many subsequent accounts, for having set fire, as it were, to that waiting tender box: the annual celebration of the ancient victory over the Gun-Powder Plot.

46. Thomas Babington Macaulay, "Francis Bacon," Critical and Historical Essays (London, 1961), 2:371.

47. Letters and Memories, 1:239, 240; quoted in Walter Houghton, The Victorian Frame of Mind (New Haven, 1957), p. 44.

48. Yeast (New York:1851), ch. 4 pp. $79,80$.

49. Pugin's virtually unique effort at the exhibition to preserve a Gothic unity and chaseness of style-his "Medieval Court" was set apart from the other displays, so full of Victorian bulges and curves and gutta-percha affronts to taste-has occasioned a modern authority to muse: "Gothic gloom or Crystal Palace, 1851 had two faces ... Candles and gaslight and dreams of electricity; medieval armor and Birmingham hardware; pyramids of soap and cries of 'No-Popery'-all these were part of 1851." Asa Briggs, Pictorian Poeple: A Reassessment of Persons and Themes, 1851-67 
raised the question whether the universe could be explained and its value measured by glass and iron. While some would shrug with Macaulay, many more would rather smother the question, as Kingsley did, in the language of sentimental religion, and with him conclude that while one would opt for civilization over a false and superstitious sanctity, in a higher sense, civilization was sanctity. This of course is what Victorians tended to do with every important issue: smother it in the rhetoric of religiosity. It was their chief hedge against the new world of science, technology and bureaucracy.

As already indicated, central to an understanding of the Papal Aggression is the role played by this kind of rhetoric. The papal brief, Wiseman's pastoral, Russell's Durham Letter, the press and pulpit all elevated the issue to a level of principalities and powers unmatched by anything here below. Wiseman strove through words to realize the great dream of conquering England again for the faith and by exalted language to cover the miserable quarrels and petty factional disputes which actually constituted the English Catholic scene.

But such words touched all the deepest feelings of the Protestant majority, and for a brief season they were able to luxuriate in the ancient battle with popery. By the spring of 1851 the language of alarm and outrage had become threadbare, and nothing is clearer than the embarrassment of Russell and his government when stuck in the parliament of 1851 with an issue from which all sensible minds had turned away.

Finally it should be noted that in their quite different ways, both the Papal Aggression and the Crystal Palace presented the perennial problem of authority. One pointed forward, to all those -isms of the future: nationalism, industrialism, imperialism, and the -ism having for the later Victorians the most authoritative vocabulary of all, scientism. No-Popery, however, pointed backward, to the authority of an impeccable Protestant Bible, to a history rich in Spanish armadas, Gun Powder plots and Gordon Riots, to their own nightly sermons on the Whore of Babylon in the huge auditorium of Exeter Hall and more profoundly to the world of Coleridge and the early Gladstone wherein there was found a divinely joined identity of church and state.

Either direction could and often did lead to bigotry, intellectual dishonesty and on occasion a desperate unease. As Sir Llewellyn Woodward some years ago wrote regarding the various levels of meaning the Great Exhibition represented, "The visibility of progress was undoubted. . . . Nevertheless something is wrong, or I should say, something is missing from the vision of progress. For one thing, there is too little sense of mystery. The warning that the range of the known is and must remain far smaller than the range of the unknown recurs as something which could not be said too often in the writings of the greatest Victorians. The Victorians were living dangerously, far more dangerously than they knew. The world was much stranger than their machinery, and the nature of man more fragile and at the same time more unfathomable."50

(Chicago, 1955), p. 37. At one point John Bright came upon Sir James Graham looking bemused. He explained that as he walked through the displays dedicated to the twin themes of "peace and civilization" his mind kept reverting to the previous autumn and the storm of the Papal Aggression. It must have been a reflection common to many thoughtful Victorians.

50. Ernest Llewellyn Woodward, "1851 and the Visibility of Progress," in B.B.C. Third Program, Ideas and Beliefs of the Victorians, $A n$ Historical Revaluation of the $\nabla$ iotorian Age (Iondon, 1949), p. 62. 